\title{
Physiological responses to salt stress by native and introduced red algae in New Zealand
}

\author{
Vanessa Gambichler ${ }^{1}$, Giuseppe C. Zuccarello ${ }^{2}$ and Ulf Karsten ${ }^{1, *}$ \\ ${ }^{1}$ Institute of Biological Sciences, Applied Ecology and Phycology, University of Rostock, D-18059 Rostock, Germany \\ ${ }^{2}$ School of Biological Sciences, Victoria University of Wellington, Wellington 6140, New Zealand
}

Intertidal macroalgae are regularly exposed to hypo- or hypersaline conditions which are stressful. However, red algae in New Zealand are generally poorly studied in terms of salinity tolerance. Consequently, two native (Bostrychia arbuscula W. H. Harvey [Ceramiales], Champia novae-zelandiae [J. D. Hooker \& Harvey] Harvey [Rhodymeniales]) and one introduced red algal taxon (Schizymenia spp. J. Agardh [Nemastomatales]) were exposed for 5 days in a controlled salt stress experiment to investigate photosynthetic activity and osmotic acclimation. The photosynthetic activity of $B$. arbuscula was not affected by salinity, as reflected in an almost unchanged maximum quantum yield $\left(\mathrm{F}_{\mathrm{v}} / \mathrm{F}_{\mathrm{m}}\right)$. In contrast, the $\mathrm{F}_{\mathrm{v}} / \mathrm{F}_{\mathrm{m}}$ of C. novae-zelandiae and Schizymenia spp. strongly decreased under hypo- and hypersaline conditions. Treatment with different salinities led to an increase of the total organic osmolyte concentrations with rising salt stress in B. arbuscula and Schizymenia spp. In C. novae-zelandiae the highest organic osmolyte concentrations were recorded at $\mathrm{S}_{\mathrm{A}} 38$, followed by declining amounts with further hypersaline exposure. In B. arbuscula, sorbitol was the main organic osmolyte, while the other taxa contained floridoside. The data presented indicate that all three red algal species conspicuously differ in their salt tolerance. The upper intertidal B. arbuscula exhibited a wide salinity tolerance as reflected by unaffected photosynthetic parameters and strong sorbitol accumulation under increasing salinities, and hence can be characterized as euryhaline. In contrast, the introduced Schizymenia spp. and native C. novae-zelandiae, which preferentially occur in the mid-intertidal, showed a narrower salinity tolerance. The species-specific responses reflect their respective vertical positions in the intertidal zone.

Key Words: floridoside; hypersaline; maximum quantum yield; organic osmolytes; sorbitol

\section{INTRODUCTION}

Ecophysiological traits characterize individual algal species and their response patterns to abiotic and biotic factors (Lüning 1990), and are based on the concept of the fundamental niche versus the realized niche after Hutchinson (1957). Hutchinson (1957) considered the niche as an array of biotic and abiotic parameters under which a species is able to persist and maintain population sizes. This ecological concept was at the beginning restricted to terrestrial organisms, but later transferred also to marine seaweeds (Marcelino and Verbruggen 2015). The latter authors reviewed ecological niche models for invasive seaweeds and highlight this important approach to better understand and monitor whether invasive species are likely to establish and spread in a new habitat.

In the intertidal zone macroalgae have to tolerate
(1) $\$$ This is an Open Access article distributed under the terms of the Creative Commons Attribution Non-Commercial License (http://creativecommons.org/licenses/by-nc/3.0/) which permits unrestricted non-commercial use, distribution, and reproduction in any medium, provided the original work is properly cited.
Received March 15, 2021, Accepted June 10, 2021

*Corresponding Author

E-mail: ulf.karsten@uni-rostock.de Tel: +49-381-4986090, Fax: +49-381-4986072 
changing and fluctuating environmental factors such as light, temperature, salinity and mechanical forces (Lüning 1990, Davison and Pearson 1996). Major problems intertidal seaweeds have to cope with are diurnal and seasonal changes of these abiotic factors (Davison and Pearson 1996, Bischof et al. 2006, Diehl et al. 2019). Salinity in intertidal zones is one of the key stressors which is influenced by tides, hydrological conditions, wind, precipitation and evaporation (Karsten 2012). During low tides intertidal macroalgae are exposed to hypo- or hypersaline conditions (Kirst 1990). Hyposaline conditions are caused by rain, snow or melt water (Karsten 2012). In contrast, hypersaline conditions emerge through evaporation during summer or freezing-out of freshwater during winter (Karsten 2012). As a result macroalgae living in the intertidal zone have developed various protective mechanisms (Kirst 1990, Karsten 2012, Scherner et al. 2013, van Ginneken 2018). Protective mechanisms at the physiological level include osmotic acclimation, which reflects the salinity tolerance of macroalgae (Kirst 1990). Photosynthesis and respiration are strongly affected by salinity changes (Sudhir and Murthy 2004, Scherner et al. 2013). High salinities typically inhibit at least three sites in the photosynthetic machinery: (1) photoactivation of electron flow on the reducing site of photosystem I, (2) electron flow on the water splitting site of photosystem II, (3) transfer of light energy between pigment complexes (Kirst 1990). Physiological parameters such as the rates of survival, growth, photosynthesis, respiration and reproduction are used to quantify the range of salinity tolerance of macroalgae (Kirst 1990, Eggert et al. 2007, Fredersdorf et al. 2009). The shape of the growth or photosynthesis rate curve (narrow versus wide) in various salinities characterizes algal species as steno- or euryhaline (Karsten 2012). Euryhaline macroalgae are typically eulittoral species, while stenohaline species are mainly sublittoral (Russell 1987). Osmolytes, low-molecularweight organic solutes, are synthesized and accumulated or degraded under salinity stress (Ben-Amotz and Avron 1983, Angell et al 2015). Additionally, organic osmolytes exert further biochemical functions as they can act as compatible solutes (protect enzymes and structural molecules), i.e., these compounds are highly soluble in the cytoplasm and non-toxic at high concentrations (Kirst 1990, Shetty et al. 2019). In the last decades much progress has been made in identifying low-molecular-weight carbohydrates, especially in red algae (Karsten 2012), and compounds such as floridoside, mannitol, dulcitol, sorbitol and trehalose have been reported (Karsten et al. 1997, Eggert and Karsten 2010). Many species within the
Florideophyceae typically contain floridoside (Karsten et al. 2007). Species within the order Ceramiales synthesize digeneaside instead of floridoside, and some genera like Bostrychia additionally synthesize polyols such as sorbitol, dulcitol, or even mannitol (e.g., Caloglossa) (Karsten et al. 2005, 2007).

New Zealand's coastline has a rich diversity of macroalgae, especially red algae, but their ecophysiological traits are poorly studied (Adams 1994, Hurd et al. 2004, Nelson 2013). Few studies have been conducted on stress response patterns within intertidal macroalgae in New Zealand (Lamare et al. 2004, Schweikert et al. 2011, Muangmai et al. 2015, Bollen et al. 2016, Diehl et al. 2019). Diehl et al. (2019), for example, investigated seasonal changes on stress metabolites (UV-absorbing mycosporine-like amino acids and heterosides) in the intertidal red alga Pyropia plicata W. A. Nelson, and they reported consistently high amounts of all analysed compounds which mitigate against environmental changes typical of the intertidal zone. Growth rates of cryptic species of Bostrychia intricata (Bory) Montagne in respect of salinity and temperature were also studied (Muangmai et al. 2015). These authors showed that all strains grew at the full range of salinities and temperatures tested, but revealed strong difference in their specific growth rates. Bollen et al. (2016) investigated the salinity and temperature tolerance of two native New Zealand brown macroalgae Lessonia variegata J. Agardh and Ecklonia radiata (C. Agardh) J. Agardh in comparison to the introduced species Undaria pinnatifida (Harvey) Suringar, and Undaria displayed broader tolerance to the experimental stressors than native kelps.

Many macroalgae in New Zealand are indigenous (Adams 1994, Nelson 1994, Nelson et al. 2013) but non-indigenous taxa continue to arrive due to intense ship traffic, changing environmental conditions and increased monitoring (D'Archino and Zuccarello 2014, 2021). Invasive species are often more tolerant to abiotic conditions than native ones (Bollen et al. 2016). In the last few years, many introduced macroalgal species have been reported in New Zealand, such as the red alga Schizymenia apoda (J. Agardh) J. Agardh (D'Archino et al. 2007, 2015, Nelson et al. 2013, D'Archino and Zuccarello 2014, 2021, Garbary et al. 2020), but their establishment, spread and ecophysiological traits in the new habitat are mainly unknown.

The present study compared two native red algal species with two introduced red algae in respect of their salinity tolerance. Bostrychia arbuscula W. H. Harvey (Ceramiales, Rhodomelaceae) and Champia novae-zelandiae (J. D. Hooker \& Harvey) Harvey (Rhodymeniales, 
Champiaceae) are native to New Zealand and distributed on the North Island, the South Island, the Chatham Islands, and Stewart Island (Nelson 2013). Bostrychia species as intertidal to supralittoral macroalgae are described as euryhaline, as many studies indicate their broad salinity tolerance (Karsten et al. 1995, 1996a, Muangmai et al. 2015). Champia novae-zelandiae is found from the intertidal to the upper subtidal (Nelson 2013), and based on its zonation expected to be less euryhaline compared to Bostrychia. The introduced species belongs to the genus Schizymenia (Nemastomatales, Schizymeniaceae) with currently 10 taxonomically accepted species (Guiry and Guiry 2020). Schizymenia apoda (J. Agardh) J. Agardh and S. dubyi (Chauvin ex Duby) J. Agardh are both known from different locations around the world (Gabriel et al. 2011, Ramirez et al. 2012, Saunders et al. 2015, Gunnarsson et al. 2020). In 2014, S. apoda was first noted as an introduced species to New Zealand (D'Archino and Zuccarello 2014), and more recently $S$. dubyi has been discovered in Wellington Harbour (D'Archino and Zuccarello 2020, and unpublished observations). Both taxa are mainly found in the low intertidal to shallow subtidal and in large tidal pools (Guiry and Guiry 2020).

The aim of this study was to compare the salinity tolerance of the two native and the introduced species to better understand the respective response patterns with an emphasis on the function of organic osmolytes. The hypothesis that B. arbuscula and C. novae-zelandiae as native species are well adapted to their intertidal habitat in New Zealand with highly fluctuating salinities was tested. Hence, it was expected that both native species show a higher salt tolerance than the introduced Schizymenia spp.

\section{MATERIALS AND METHODS}

\section{Species collections}

All three algae (Bostrychia arbuscula, Champia novae-zelandiae and Schizymenia spp.) were collected in winter from different collection spots for the salt stress experiments. On the date of collection the salinity was measured, using a Pocket Refractometer (PAL-06S; Atago, Tokyo, Japan). An overview of the location, the date of collection and the salinity at each collection spot is shown in the Supplementary Table S1. More details on the collection areas and the abiotic data are found in Gambichler et al. (2021).

For the salinity experiment, we had to deal with the is- sue of distinguishing the two Schizymenia species (S. apoda and S. dubyi) morphologically, which is very difficult, so a molecular survey was done to identify both taxa in the Whairepo Lagoon (Gambichler et al. 2021). Based on the similarity in the biochemical profiles and due to the taxonomic difficulty of separating both taxa (Gambichler et al. 2021), the data used in the present study is a mix of both Schizymenia spp.

\section{Experimental set up}

All specimens were brought to the laboratory, soon after collection, and acclimated for $24 \mathrm{~h}$ in seawater $\left(38 \mathrm{~S}_{\mathrm{A}}\right)$ with aeration, light (photoperiod $12 \mathrm{~h}$ light-dark cycle, irradiance: $55 \pm 5 \mu \mathrm{moL}$ photons $\mathrm{m}^{-2} \mathrm{~s}^{-1}$ ) and temperature $\left(14 \pm 1^{\circ} \mathrm{C}\right)$ conditions. The salt stress experiments were performed for 5 days. During the experiment the cleaned specimens were stored in $200 \mathrm{~mL}$ plastic containers filled with sterile seawater of seven different salinities (absolute salinity: $1,5,15,20,38,45$, and $60 \mathrm{~S}_{\mathrm{A}}$ ) with three replicates for each salinity. The different salinities were prepared by either diluting seawater with ultrapure water $\left(\mathrm{dH}_{2} \mathrm{O}\right)$ or by adding sea salt (Aquaforest, Poland) to increase salinities. Additionally $1 \mathrm{~mL}$ of $1 \mathrm{mM} \mathrm{NaHCO}_{3}, 5$ $\mathrm{mL}$ of modified Provasoli's medium (PES) (after West and McBride 1999) and $200 \mu \mathrm{L}$ of $\mathrm{GeO}_{2}\left(1 \mathrm{~g} \mathrm{~mL}^{-1}\right)$ were added to $1 \mathrm{~L}$ of media to prevent diatom growth and ensure the availability of sufficient bicarbonate for photosynthesis. The medium was changed on the second day. At the end of the experiment all samples were oven dried $\left(60^{\circ} \mathrm{C}\right)$ and stored in the dark until further analyses. The organic osmolytes in the dried algal samples were measured with high performance liquid chromatography (HPLC 1260 Infinity System; Agilent Technologies GmbH, Waldbronn, Germany). A detailed description of the extraction method and the measurement of the organic osmolytes are found in Gambichler et al. (2021).

The in vivo chlorophyll $a$ fluorescence of each sample and an in situ sample without treatment were measured before the start of the experiment (day 1) and every day during the salt stress experiments until day 5 , with an underwater pulse-amplitude-modulated fluorometer (Diving-PAM; Walz GmbH Mess- und Regeltechnik, Effeltrich, Germany). The maximum quantum yield $\left(\mathrm{F}_{\mathrm{v}} / \mathrm{F}_{\mathrm{m}}\right)$ was always measured after $10 \mathrm{~min}$ of dark acclimation and calculated with the fluorescence maximum $\left(\mathrm{F}_{\mathrm{m}}\right)$ and $\mathrm{F}_{0}$ the minimum level of fluorescence $\left(\mathrm{F}_{\mathrm{v}} / \mathrm{F}_{\mathrm{m}}=\left(\mathrm{F}_{\mathrm{m}}-\mathrm{F}_{0}\right) / \mathrm{F}_{\mathrm{m}}\right)$. All values were calculated and processed in Excel 2010. Detailed tables of all 5-day measurement series for all three algae are provided in the Supplementary Tables S2-S4. 


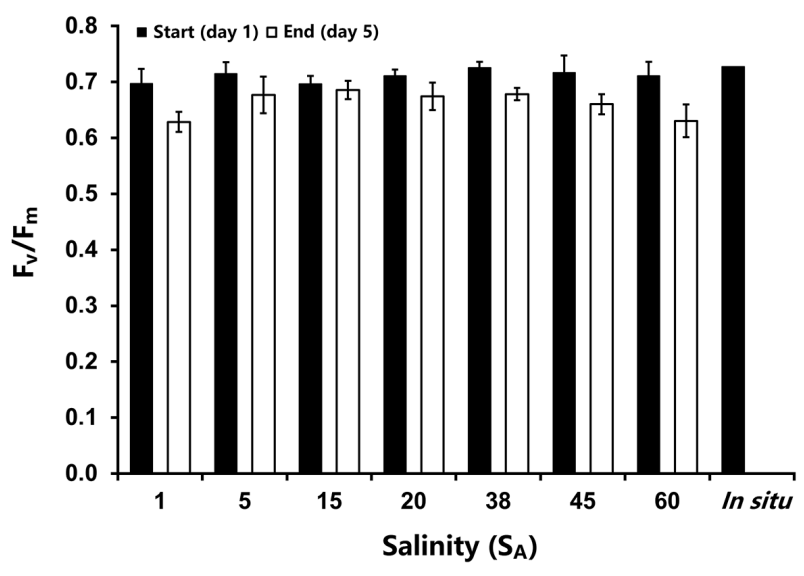

Fig. 1. In vivo chlorophyll a fluorescence (maximum quantum yield, $\mathrm{F}_{\mathrm{v}} / \mathrm{F}_{\mathrm{m}}$ ) of Bostrychia arbuscula before (day 1, grey bar) and after (day 5 , white bar) the salt stress experiment, range from 1 to 60 absolute salinity $\left(\mathrm{S}_{\mathrm{A}}\right)$. The in situ measurement was undertaken on freshly collected thalli from the field (no treatment). Values are means $\pm S D(n=$ 3 replicates).

The $\mathrm{F}_{\mathrm{v}} / \mathrm{F}_{\mathrm{m}}$ represents an indicator of the photosynthetic performance of the alga and is often affected under stress exposure (Maxwell and Johnson 2000). The PAM set up was determined for every algal species individually (see Supplementary Table S5).

\section{Statistics}

All statistical analyses were performed using SPSS Statistics 25 (IBM Corp., Armonk, NY, USA). To test for interaction effects between the $\mathrm{F}_{\mathrm{v}} / \mathrm{F}_{\mathrm{m}}$ and the salinity a mixed ANOVA (General linear model with repeated measures) with one between-subject (treatment = salinity as independent variable) and one within-subject (day $=$ start $F_{v} /$ $F_{m}$ and end $F_{v} / F_{m}$ as dependent variable) was performed. To analyse significant differences between the organic osmolytes concentration and the salinity, a one-way ANOVA was performed for each alga with the organic osmolyte content as the dependent variable and salinity as the independent variable (7 levels). Depending if the assumptions were met (normality with the Shapiro-Wilk Test and Q-Q-Plots, outliers with a boxplot, homogeneity of variances with Levene's test at $p>0.05$ ), the appropriate tests were interpreted. The violation of normality in some cases were neglected due to the small sample and replicate sizes (Underwood 1997). If the ANOVA or Welch-ANOVA (for violation of Levene's test) showed significant differences $(\mathrm{p}<0.05)$, a post-hoc Tukey's honestly significant difference or a Games-Howell post-hoc test was analysed for more detailed interpretation and case

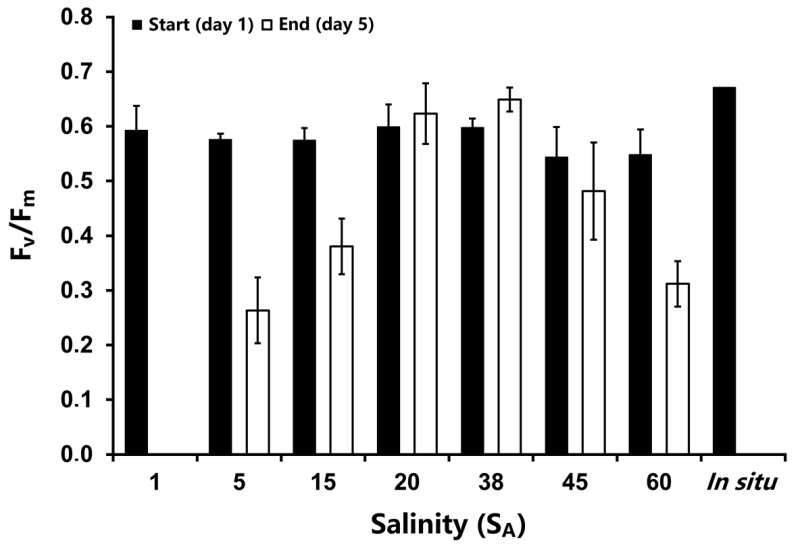

Fig. 2. In vivo chlorophyll a fluorescence (maximum quantum yield, $\mathrm{F}_{\mathrm{v}} / \mathrm{F}_{\mathrm{m}}$ ) of Champia novae-zelandiae before (day 1, grey bar) and after (day 5, white bar) the salt stress experiment, range from 1 to 60 absolute salinity $\left(\mathrm{S}_{\mathrm{A}}\right)$. The in situ measurement was undertaken on freshly collected thalli from the field (no treatment). Values are means \pm SD ( $n$ $=3$ replicates).

lettering of the graphs. All statistical results are found in detail in the Supplementary Tables S6-S11.

\section{RESULTS}

\section{Photosynthetic activity}

Bostrychia arbuscula exhibited high initial $\mathrm{F}_{\mathrm{v}} / \mathrm{F}_{\mathrm{m}}$ values between 0.70 and 0.73 . Exposure to different salt concentrations led to only minor decreases in the $\mathrm{F}_{\mathrm{v}} / \mathrm{F}_{\mathrm{m}}$, in the range of 0.63 to 0.69 , whereby the strongest effect could be observed at the lowest $\left(1 \mathrm{~S}_{\mathrm{A}}\right)$ and the highest $\left(60 \mathrm{~S}_{\mathrm{A}}\right)$ salinity tested (mixed ANOVA: $\mathrm{F}(1,14)=30.69, \mathrm{p}<0.05$ ) (Fig. 1). There was no significantly difference found between the treatments but the $F_{v} / F_{m}$ values between day 1 and 5 were significantly different. All statistical details can be found in the Supplementary Table S6.

Compared to B. arbuscula, the $\mathrm{F}_{\mathrm{v}} / \mathrm{F}_{\mathrm{m}}$ values in Champia novae-zelandiae were slightly lower in the in situ sample (0.67) and the thalli at the beginning of the salt experiment (0.54-0.60) (Fig. 2). Salinity had a very strong effect on $\mathrm{F}_{\mathrm{v}} / \mathrm{F}_{\mathrm{m}}$ after 5 days of treatment (ANOVA: $\mathrm{F}(6,20)$ $=36.708, \mathrm{p}<0.05)$ (see Supplementary Table S7). At $1 \mathrm{~S}_{\mathrm{A}}$ in vivo chlorophyll $a$ fluorescence could not be measured, and at $20 \mathrm{~S}_{\mathrm{A}}$ and $38 \mathrm{~S}_{\mathrm{A}}$, the optimum salinities, the values of $\mathrm{F}_{\mathrm{v}} / \mathrm{F}_{\mathrm{m}}$ at day 5 were slightly higher than those at the beginning (Fig. 2). Hyposaline conditions (5 and $15 \mathrm{~S}_{\mathrm{A}}$ ) were accompanied by a strong decline in $\mathrm{F}_{\mathrm{v}} / \mathrm{F}_{\mathrm{m}}$ and also exposure to hypersaline media of 45 and $60 \mathrm{~S}_{\mathrm{A}}$ led to de- 


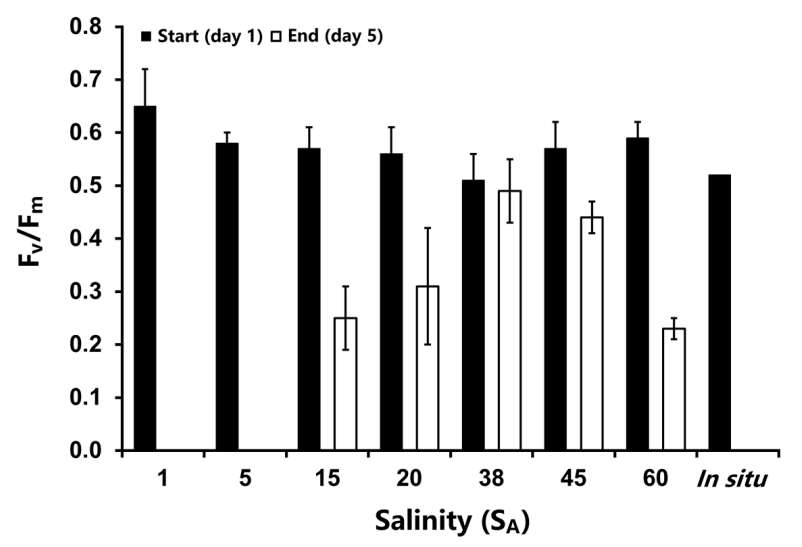

Fig. 3. In vivo chlorophyll a fluorescence (maximum quantum yield, $\mathrm{F}_{\mathrm{v}} / \mathrm{F}_{\mathrm{m}}$ ) of Schizymenia spp. before (day 1, grey bar) and after (day 5 , white bar) the salt stress experiment, range from 1 to 60 absolute salinity $\left(\mathrm{S}_{\mathrm{A}}\right)$. The in situ measurement was undertaken on freshly collected thalli from the field (no treatment). Values are means $\pm S D(n=$ 3 replicates).

creasing $\mathrm{F}_{\mathrm{v}} / \mathrm{F}_{\mathrm{m}}$ values.

Schizymenia spp. exhibited the narrowest salinity tolerance of the taxa tested as the $\mathrm{F}_{\mathrm{v}} / \mathrm{F}_{\mathrm{m}}$ was completed inhibited at 1 and $5 \mathrm{~S}_{\mathrm{A}}$ (Fig. 3), as reflected in bleached and hence dead thalli. The highest $F_{v} / F_{m}$ value was at $38 S_{A}$ and hypo- and hypersaline conditions exposure led both to strongly declining photosynthetic activity (WelchANOVA: $\mathrm{F}(4,4.709)=13.575, \mathrm{p}<0.05)$. The start values of $\mathrm{F}_{\mathrm{v}} / \mathrm{F}_{\mathrm{m}}$ were similar, ranging between $0.51 \pm 0.05$ and 0.65 \pm 0.07 . After 5 days, the $F_{v} / F_{m}$ of the treatments 15 and $60 \mathrm{~S}_{\mathrm{A}}$ decreased strongly compared to the yield values at day 1 (Fig. 3, Supplementary Tables S4 \& S8 for statistical details).

\section{Organic osmolytes}

Bostrychia arbuscula contained as the main organic osmolytes the polyol sorbitol and the heteroside digenaside (Fig. 4). The total concentrations of both osmolytes changed significantly between the different salinity treatments (one-way ANOVA: $\mathrm{F}(6,14)=8.263, \mathrm{p}<0.05$ ). The total organic osmolyte contents increased with higher salinity from 166 to $287 \mathrm{mmol} \mathrm{kg}^{-1} \mathrm{DW}$ (Fig. 4). However, both osmolytes showed different response patterns in $B$. arbuscula, as the digeneaside concentration had lower variation then that of sorbitol. The digeneaside amounts were slightly higher in the hyposaline treatments (1 to 15 $\mathrm{S}_{\mathrm{A}}$ ) with about $116 \mathrm{mmol} \mathrm{kg}^{-1} \mathrm{DW}$ than under hypersaline conditions (45 and $60 \mathrm{~S}_{\mathrm{A}}$ ) with approximately $90 \mathrm{mmol}$ $\mathrm{kg}^{-1} \mathrm{DW}$ (Fig. 4). For the in situ sample a digeneaside con-

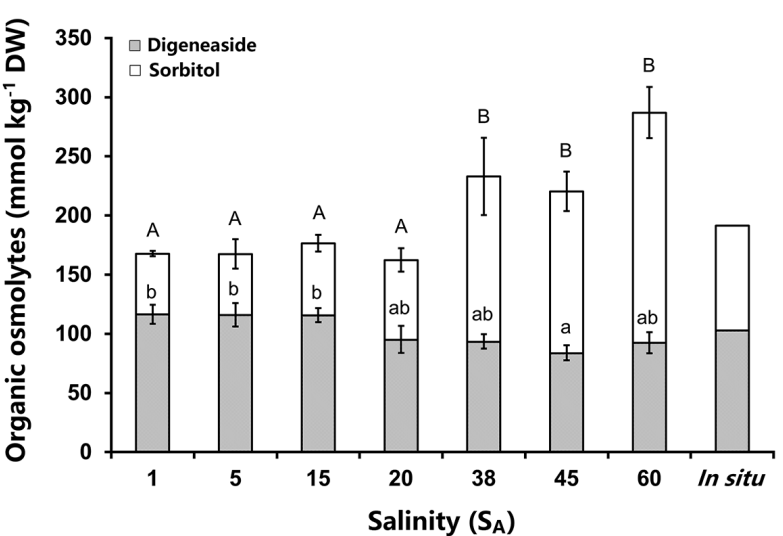

Fig. 4. Organic osmolyte concentrations in Bostrychia arbuscula after 5 days treatment with different salinities. The in situ measurement was undertaken on freshly collected thalli from the field (no treatment). Lower case and capital letters indicate significant differences in the digeneaside and sorbitol concentrations between the different salinities, respectively. Values are means $\pm S D$ ( $n=3$ replicates).

tent of $103 \mathrm{mmol} \mathrm{kg}^{-1} \mathrm{DW}$ was measured. The sorbitol values increased with higher salinities and ranged from 50 to $195 \mathrm{mmol} \mathrm{kg}^{-1}$ DW (Fig. 4). The highest sorbitol amounts with 140 up to $200 \mathrm{mmol} \mathrm{kg}^{-1} \mathrm{DW}$ were measured at higher salinities $\left(38,45\right.$, and $60 \mathrm{~S}_{\mathrm{A}}$ ) and these were significantly different to the lower sorbitol concentrations between 1 and $20 \mathrm{~S}_{\mathrm{A}}$ (Fig. 4). The sorbitol level of the in situ sample was relatively low, $89 \mathrm{mmol} \mathrm{kg}^{-1} \mathrm{DW}$. Overall the proportion of sorbitol to digeneaside changed at the higher salinities. Digeneaside dominated sorbitol in the hyposaline media (approx. $56: 44$ ) while under hypersaline conditions sorbitol dominated digeneaside (approx. 64 : 36). All statistical details to the significant differences in Fig. 4 can be found in the Supplementary Table S9.

In the in situ sample and in the samples from the salt experiment of C. novae-zelandiae the heteroside floridoside was identified as the only organic osmolyte (Fig. 5). The concentrations of floridoside changed significantly between the different salinities (one-way ANOVA: $\mathrm{F}(5,12)$ $=62.831, \mathrm{p}<0.05)$ (Supplementary Table S10). The highest floridoside concentration was measured at $38 \mathrm{~S}_{\mathrm{A}}$ (184 mmol kg-1 DW) but this was not significantly differ-

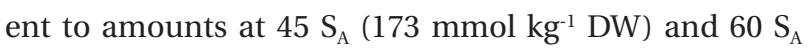
(156 mmol kg-1 DW). Reversely, the floridoside content strongly decreased from 38 to $15 \mathrm{~S}_{\mathrm{A}}$ and $5 \mathrm{~S}_{\mathrm{A}}$ hyposaline treatments (Fig. 5). The two lowest amounts of floridoside at $5 \mathrm{~S}_{\mathrm{A}}\left(6 \mathrm{mmol} \mathrm{kg}{ }^{-1} \mathrm{DW}\right)$ and $\mathrm{S}_{\mathrm{A}} 15\left(11 \mathrm{mmol} \mathrm{kg}^{-1} \mathrm{DW}\right)$ were significantly different to all other salinities $(\mathrm{p}<0.05)$ (Supplementary Table S7). The in situ sample showed a similar floridoside content $\left(97 \mathrm{mmol} \mathrm{kg}{ }^{-1} \mathrm{DW}\right)$ to those 


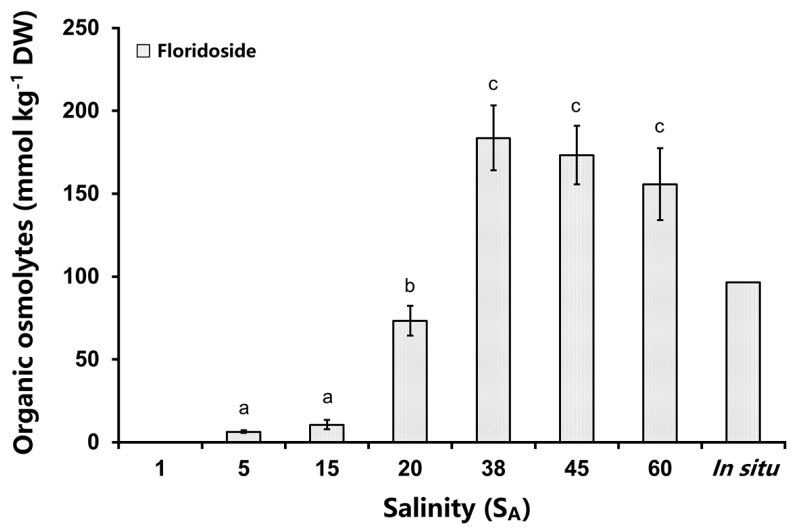

Fig. 5. Organic osmolyte concentrations in Champia novae-zelandiae after 5 days treatment with different salinities. The in situ measurement was undertaken on freshly collected thalli from the field (no treatment). Lower case letters indicate significant differences in the floridoside concentrations between the different salinities. Values are means $\pm S D$ ( $n=3$ replicates $)$.

at $20 \mathrm{~S}_{\mathrm{A}}\left(73 \mathrm{mmol} \mathrm{kg}^{-1} \mathrm{DW}\right)$ (Supplementary Table S10).

Floridoside was also the main organic osmolyte in Schizymenia spp. after the 5-day incubation and in the in situ sample (Fig. 6). The contents of floridoside increased continuously from hyposaline to hypersaline media (Fig. 6). The two lowest values of floridoside at 15 $\mathrm{S}_{\mathrm{A}}\left(22 \mathrm{mmol} \mathrm{kg}^{-1} \mathrm{DW}\right)$ and $20 \mathrm{~S}_{\mathrm{A}}\left(33 \mathrm{mmol} \mathrm{kg}^{-1} \mathrm{DW}\right)$ which were significantly different to the two highest amounts of floridoside at $45 \mathrm{~S}_{\mathrm{A}}\left(146 \mathrm{mmol} \mathrm{kg}{ }^{-1} \mathrm{DW}\right)$ and $60 \mathrm{~S}_{\mathrm{A}}(162$ mmol kg-1 DW) (Welch-ANOVA: $\mathrm{F}(4,4.855)=169.78, \mathrm{p}<$ $0.05)$ (Supplementary Table S11). The samples of $1 \mathrm{~S}_{\mathrm{A}}$ and $5 \mathrm{~S}_{\mathrm{A}}$ were not tested for floridoside concentrations as no in vivo chlorophyll $a$ fluorescence was measured (Figs 3 \&6).

Besides floridoside, an additional, chemically unknown compound was detected during HPLC analysis in Schizymenia spp. (Gambichler et al. 2021). This unknown compound varied between the different salinities (Supplementary Fig. S1). In hyposaline treatments (15 and 20 $\mathrm{S}_{\mathrm{A}}$ ) the unknown compound dominated floridoside making up $>50 \%$ of both compounds, while under normal salinity and hypersaline conditions the percentage proportion decreased (Supplementary Fig. S1).

\section{DISCUSSION}

The maximum quantum yield $\left(\mathrm{F}_{\mathrm{v}} / \mathrm{F}_{\mathrm{m}}\right)$ was evaluated as an important parameter for characterizing the physiological status of the respective alga under salt stress (Max-

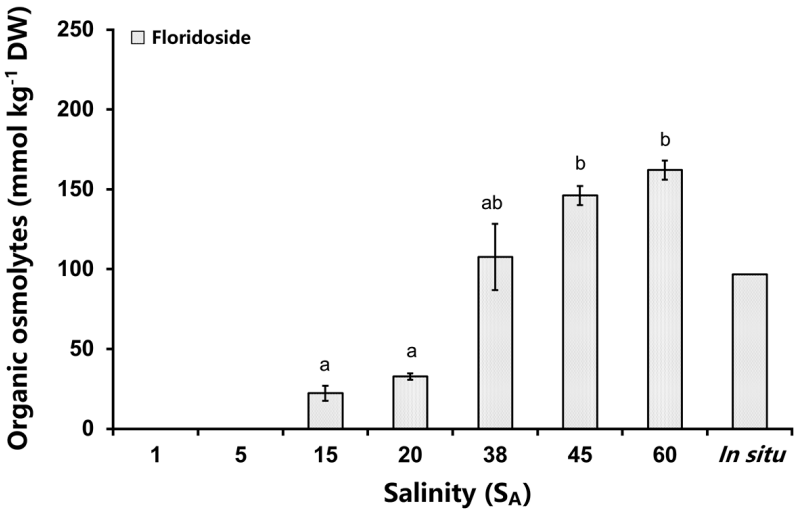

Fig. 6. Organic osmolyte concentrations in Schizymenia spp. after 5 days treatment with different salinities. The in situ measurement was undertaken on freshly collected thalli from the field (no treatment). Lower case letters indicate significant differences in the floridoside concentrations between the different salinities. Values are means \pm $\mathrm{SD}(\mathrm{n}=3$ replicates $)$.

well and Johnson 2000). The in vivo chlorophyll $a$ fluorescence measurements of Bostrychia arbuscula showed no significant decline of the $F_{v} / F_{m}$ after a 5-day-incubation in different salinities. This indicates that $B$. arbuscula was neither stressed by the treatments, pointing to a broad salinity tolerance resulting in a wide fundamental niche in respect to this environmental factor. Different studies support this and describe Bostrychia species as being generally euryhaline and extremophilic (Karsten and Kirst 1989, Karsten et al. 1995, 1996a, Broderick and Dawes 1998, Muangmai et al. 2015). This broad photosynthetic tolerance was also found in other intertidal red algae, such as, for example, Bangiopsis subsimplex (Montagne) F. Schmitz from the Baltic Sea (Eggert et al. 2007). In contrast, for Pyropia plicata which is also a high intertidal species and co-occurring with B. arbuscula, a strong decrease of the $\mathrm{F}_{\mathrm{v}} / \mathrm{F}_{\mathrm{m}}$ under extreme hypo- and hypersaline conditions was observed (Diehl et al. 2019). These euryhaline traits are supported by some earlier results on B. arbuscula, which report fast and almost complete recovery from long periods of severe desiccation (Brown 1987). Analysing the organic osmolytes in B. arbuscula after 5 days of salt stress showed a clear response, with higher concentrations under hypersaline conditions. Such findings were already reported in other studies on different intertidal algae (Eggert et al. 2007, Diehl et al. 2019). In B. arbuscula only the sorbitol concentration increased with higher salinities, while the digeneaside contents remained within a similar range between 84 and $116 \mathrm{mmol} \mathrm{kg}^{-1} \mathrm{DW}$ for all salinities. A similar pattern was 
already reported for Bangiopsis subsimplex (Eggert et al. 2007). This supports the assumption that sorbitol is the dominant and regulated salt stress protective substance while digeneaside plays only a minor role, if at all, in osmotic adjustment (Karsten et al. 2005, 2007). The seasonal measurements of the organic osmolytes support this assumption, as the digeneaside concentrations did not show high fluctuations between the months while the sorbitol concentrations varied strongly (Gambichler et al. 2021). The rather unusual capability for some red algal genera to synthesize sorbitol has been interpreted as a biochemical key trait to cope with highly fluctuating environmental conditions such as in the high intertidal / supralittoral zone (Karsten 2012). Sorbitol and other polyols exert various physiological and biochemical functions that contribute to water-holding of cells during desiccation and to the stabilization of biomolecules under various stressors (Yancey 2005).

Champia novae-zelandiae was much less salinity tolerant compared to B. arbuscula as the in vivo chlorophyll $a$ fluorescence data showed a strong decline under the lowest and highest salinities tested, while at $1 \mathrm{~S}_{\mathrm{A}}$ even complete inhibition was observed. Optimum quantum yield occurred at 20 and $38 \mathrm{~S}_{\mathrm{A}}$ pointing to their fundamental niche in a rather narrow range of salinities. The results of the $\mathrm{F}_{\mathrm{v}} / \mathrm{F}_{\mathrm{m}}$ of $C$. novae-zelandiae are partly reflected in the results on the organic osmolyte concentrations, since at $1 \mathrm{~S}_{\mathrm{A}}$ no floridoside was detected and hence it was assumed that the specimens at the lowest salinity were dead, which was further supported by bleached thalli (unpublished observations).

Between 5 and $38 \mathrm{~S}_{\mathrm{A}}$ the floridoside amounts continuously increased with rising salinity, while under hypersaline conditions the concentrations remained unchanged, like control levels. This points to the capability of C. novae-zelandiae for osmotic acclimation only under hyposaline stress but not under hypersaline conditions. The described response pattern might be explained by the low intertidal position on the shore, which exhibits lower salinity fluctuations compared to the upper intertidal / supralittoral. The physiological role of floridoside as an organic osmolyte in red algae is well described in the literature (e.g., Kirst and Bisson 1979, Wiencke and Läuchili 1981, Kirst 1990) but also recent studies confirm that floridoside contents increase or decrease under hypersaline or hyposaline conditions, respectively (SimonColin et al. 2002, Lv et al. 2019). The first experimental proof of a protective function of floridoside on in vitro enzyme activity was provided by Karsten et al. (1996b). These authors showed that malate dehydrogenase and glucose-6-phosphate dehydrogenase extracted from the mangrove red alga Catenella nipae were strongly inhibited by rising $\mathrm{NaCl}$ concentrations up to $600 \mathrm{mM}$, while equimolar concentrations of floridoside did not inhibit enzyme activity.

Although macroalgae are capable of adjusting to new salinity conditions within a few days (Kirst 1990), it could be possible that C. novae-zelandiae relies on inorganic ions as osmolytes under hypersaline conditions. This would save energy as de novo floridoside biosynthesis is metabolically more expensive compared to ion uptake ( $>50$ fold) (Karsten 2012). The energy requirements for ion transport across membranes in the green macroalga Ulva lactuca are equivalent to only $10-30 \%$ of the energy provided by respiration (Ritchie 1988). There exists good evidence that many inorganic ion transporters in macroalgae are generally fast and energetically cheap compared with the cost for biosynthesis of organic osmolytes (Kirst 1990).

The introduced Schizymenia spp. was even less salt tolerant then C. novae-zelandiae as reflected in complete inhibition of the $\mathrm{F}_{\mathrm{v}} / \mathrm{F}_{\mathrm{m}}$ at both 1 and $5 \mathrm{~S}_{\mathrm{A}}$. These data are supported by the observation that the thalli started to bleach during hyposaline treatment thereby losing pigments (data not shown). In addition, at 15 and $60 \mathrm{~S}_{\mathrm{A}}$ the $\mathrm{F}_{\mathrm{v}} / \mathrm{F}_{\mathrm{m}}$ was also strongly inhibited. All these data clearly indicate stenohaline features of Schizymenia spp., which is in agreement with the preferential occurrence in tidal rock pools, where this taxon is mainly submerged. Like in C. novae-zelandiae, floridoside was the main organic osmolyte in Schizymenia spp., which was up-regulated between 15 and $60 \mathrm{~S}_{\mathrm{A}}$, although there was no statistically significant difference between 45 and $60 \mathrm{~S}_{\mathrm{A}}$. Gambichler et al. (2021) discovered in seasonally taken monthly samples of Schizymenia spp., an unknown organic compound which was also found in the present study. At low salinities (15 and $20 \mathrm{~S}_{\mathrm{A}}$ ) this compound had a higher proportion than floridoside, while under hypersaline conditions its share declined. Although neither the chemical structure nor its function could be resolved yet, this unknown compound seems to play a role in osmotic acclimation of Schizymenia spp. (Gambichler et al. 2021).

This study examined the salinity tolerance of two native red algae in New Zealand and an introduced set of species, by measuring photosynthetic activity and organic osmolytes. As expected, the highest salt tolerance was found for the native high intertidal / supralittoral species B. arbuscula. In contrast, the introduced species Schizymenia spp. cannot cope with hyposaline conditions, similar to the native species $C$. novae-zelandiae. The dif- 
ferent ecophysiological response patterns correlate well with the vertical distribution on the rocky shore. As the introduced Schizymenia spp. is so stenohaline, it preferentially grows in rather protected and stable microhabitats such as tide pools.

\section{ACKNOWLEDGEMENTS}

Vanessa Gambichler thanks the DAAD for a PROMOS Scholarship supporting her research stay in New Zealand. We thank Maren Preuss for her help collecting samples for this study, and all her intellectual input, as well as Ken Ryan, John van der Sman and Neville Higgison for their technical support. We also thank Julianne Müller for her support with the HPLC.

\section{CONFLICTS OF INTEREST}

The authors declare that they have no potential conflicts of interest.

\section{SUPPLEMENTARY MATERIALS}

Supplementary Table S1. Details for all three species collected for the salt stress experiment (https://www.ealgae.org).

Supplementary Table S2. Mean $(\mathrm{n}=3)$ of the in vivo chlorophyll $a$ fluorescence of Bostrychia arbuscula during 5 days of salt treatment at 7 salinities and one in situ sample (no treatment) (https://www.e-algae.org).

Supplementary Table S3. Mean $(\mathrm{n}=3)$ of the in vivo chlorophyll $a$ fluorescence of Champia novae-zelandiae during 5 days of salt treatment at 7 salinities and one in situ sample (no treatment) (https://www.e-algae.org).

Supplementary Table S4. Mean $(\mathrm{n}=3)$ of the in vivo chlorophyll $a$ fluorescence of Schizymenia spp. during 5 days of salt treatment at 7 salinities and one in situ sample (no treatment) (https://www.e-algae.org).

Supplementary Table S5. Overview of the different pulse-amplitude-modulated fluorometer (PAM) settings measured with Diving-PAM for all three algae (https:// www.e-algae.org).

Supplementary Table S6. Detailed statistical analysis of the maximum quantum yield $\left(\mathrm{F}_{\mathrm{v}} / \mathrm{F}_{\mathrm{m}}\right)$ of the salt stress experiment of Bostrychia arbuscula (https://www.e-algae.org).

Supplementary Table S7. Detailed statistical analy- sis of the maximum quantum yield $\left(\mathrm{F}_{\mathrm{v}} / \mathrm{F}_{\mathrm{m}}\right)$ of the salt stress experiment of Champia novae-zelandiae (https:// www.e-algae.org).

Supplementary Table S8. Detailed statistical analysis of the maximum quantum yield $\left(\mathrm{F}_{\mathrm{v}} / \mathrm{F}_{\mathrm{m}}\right)$ of the salt stress experiment of Schizymenia spp. (https://www.e-algae. org).

Supplementary Table S9. Detailed statistical analysis of the total organic osmolyte, digenaside, and sorbitol concentrations of Bostrychia arbuscula from the salt stress experiment (https://www.e-algae.org).

Supplementary Table S10. Detailed statistical analysis of the floridoside concentration of Champia novae-zelandiae from the salt stress experiment (https://www.ealgae.org).

Supplementary Table S11. Detailed statistical analysis of the floridoside concentration of Schizymenia spp. from the salt stress experiment (https://www.e-algae.org).

Supplementary Fig. S1. Percentage proportions of floridoside and the unknown compound of the total produced compounds of Schizymenia spp. at the end of the salt stress experiment (https://www.e-algae.org).

\section{REFERENCES}

Adams, N. M. 1994. Seaweeds of New Zealand: an illustrated guide. Canterbury University Press, Christchurch, NZ, $360 \mathrm{pp}$.

Angell, A. R., Mata, L., de Nys, R. \& Paul, N. A. 2015. Indirect and direct effects of salinity on the quantity and quality of total amino acids in Ulva ohnoi (Chlorophyta). J. Phycol. 51:536-545.

Ben-Amotz, A. \& Avron, M. 1983. Accumulation of metabolites by halotolerant algae and its industrial potential. Annu. Rev. Microbiol. 37:95-119.

Bischof, K., Gómez, I., Molis, M., Hanelt, D., Karsten, U., Lüder, U., Roleda, M. Y., Zacher, K. \& Wiencke, C. 2006. Ultraviolet radiation shapes seaweed communities. Rev. Environ. Sci. Biotechnol. 5:141-166.

Bollen, M., Pilditch, C. A., Battershill, C. N. \& Bischof, K. 2016. Salinity and temperature tolerance of the invasive alga Undaria pinnatifida and native New Zealand kelps: implications for competition. Mar. Biol. 163:194.

Broderick, M. E. \& Dawes, C. J. 1998. Seasonal photosynthetic and respiratory responses of the red alga Bostrychia tenella (Ceramiales, Rhodophyta) from a salt marsh and mangal. Phycologia 37:92-99.

Brown, M. T. 1987. Effects of desiccation on photosynthesis of intertidal algae from a southern New Zealand shore. 
Bot. Mar. 30:121-127.

D’Archino, R., Nelson, W., Yang, M. Y. \& Kim, M. S. 2015. New record of Hypnea flexicaulis in New Zealand and description of Calliblepharis psammophilus sp. nov. Bot. Mar. 58:485-497.

D’Archino, R., Nelson, W. A. \& Zuccarello, G. C. 2007. Invasive marine red alga introduced to New Zealand waters: first record of Grateloupia turuturu (Halymeniaceae, Rhodophyta). N. Z. J. Mar. Freshw. Res. 41:35-42.

D’Archino, R. \& Zuccarello, G. C. 2014. First record of Schizymenia apoda (Schizymeniaceae, Rhodophyta) in New Zealand. N. Z. J. Mar. Freshw. Res. 48:155-162.

D’Archino, R. \& Zuccarello, G. C. 2020. Schizymenia dubyi (Chauvin ex Duby) J. Agardh collected in Whairepo Lagoon, Wellington Harbour. N. Z. Mar. Exot. Species Note 113:5.

D’Archino, R. \& Zuccarello, G. C. 2021. Two red macroalgae newly introduced into New Zealand: Pachymeniopsis lanceolata (K. Okamura) Y. Yamada ex S. Kawabata and Fushitsunagia catenata Filloramo et G. W. Saunders. Bot. Mar. Advanced online publication. https://doi. org/10.1515/bot-2021-0013.

Davison, I. R. \& Pearson, G. A. 1996. Stress tolerance in intertidal seaweeds. J. Phycol. 32:197-211.

Diehl, N., Michalik, D., Zuccarello, G. C. \& Karsten, U. 2019. Stress metabolite pattern in the eulittoral red alga $P y$ ropia plicata (Bangiales) in New Zealand: mycosporinelike amino acids and heterosides. J. Exp. Mar. Biol. Ecol. 510:23-30.

Eggert, A. \& Karsten, U. 2010. Low molecular weight carbohydrates in red algae: an ecophysiological and biochemical perspective. In Seckbach, J. \& Chapman, D. J. (Eds.) Red Algae in the Genomic Age. Vol. 13. Cellular Origin, Life in Extreme Habitats and Astrobiology. Springer, Dordrecht, pp. 445-456.

Eggert, A., Nitschke, U., West, J. A., Michalik, D. \& Karsten, U. 2007. Acclimation of the intertidal red alga Bangiopsis subsimplex (Stylonematophyceae) to salinity changes. J. Exp. Mar. Biol. Ecol. 343:176-186.

Fredersdorf, J., Müller, R., Becker, S., Wiencke, C. \& Bischof, K. 2009. Interactive effects of radiation, temperature and salinity on different life history stages of the Arctic kelp Alaria esculenta (Phaeophyceae). Oecologia 160:483-492.

Gabriel, D., Schils, T., Parente, M. I., Draisma, S. G. A., Neto, A. I. \& Fredericq, S. 2011. Taxonomic studies in the Schizymeniaceae (Nemastomatales, Rhodophyta): on the identity of Schizymenia sp. in the Azores and the generic placement of Nemastoma confusum. Phycologia 50:109-121.
Gambichler, V., Zuccarello, G. C. \& Karsten, U. 2021. Seasonal changes in stress metabolites of native and introduced red algae in New Zealand. J. Appl. Phycol. 33:1157-1170.

Garbary, D. J., D’Archino, R., Flack, B., Hepburn, C. D., Nelson, W. A., Pritchard, D. \& Sutherland, J. E. 2020. First record of Bonnemaisonia hamifera (Bonnemaisoniales, Rhodophyta) in the South Pacific, from the South Island of New Zealand. N. Z. J. Mar. Freshw. Res. 54:167-176.

Guiry, M. D. \& Guiry, G. M. 2020. AlgaeBase: World-wide electronic publication, National University of Ireland, Galway. Available from: https://www.algaebase.org. Accessed Jan 20, 2020.

Gunnarsson, K., Russell, S. \& Brodie, J. 2020. Schizymenia jonssonii sp. nov. (Nemastomatales, Rhodophyta): a relict or an introduction into the North Atlantic after the last glacial maximum? J. Phycol. 56:324-333.

Hurd, C. L., Nelson, W. A., Falshaw, R. \& Neill, K. F. 2004. History, current status and future of marine macroalgal research in New Zealand: taxonomy, ecology, physiology and human uses. Phycol. Res. 52:80-106.

Hutchinson, G. E. 1957. Concluding remarks. Cold Spring Harb. Symp. Quant. Biol. 22:415-427.

Karsten, U. 2012. Seaweed acclimation to salinity and desiccation stress. In Wiencke, C. \& Bischof, K. (Eds.) Seaweed Biology: Novel Insights into Ecophysiology, Ecology and Utilization. Vol. 219. Springer, Berlin, pp. 87-107.

Karsten, U., Barrow, K. D., Nixdorf, O. \& King, R. J. 1996a. The compability with enzyme activity of unusual organic osmolytes from mangrove red algae. Aust. J. Plant Physiol. 23:577-582.

Karsten, U., Barrow, K. D., Nixdorf, O., West, J. A. \& King, R. J. 1997. Characterization of mannitol metabolism in the mangrove red alga Caloglossa leprieurii (Montagne) J.Agardh. Planta 201:173-178.

Karsten, U., Bock, C. \&West, J. A. 1995. Low molecular weight carbohydrate patterns in geographically different isolates of the eulittoral red alga Bostrychia tenuissima from Australia. Bot. Acta 108:321-326.

Karsten, U., Görs, S., Eggert, A. \& West, J. A. 2007. Trehalose, digeneaside, and floridoside in the Florideophyceae (Rhodophyta): a reevaluation of its chemotaxonomic value. Phycologia 46:143-150.

Karsten, U. \& Kirst, G. O. 1989. Incomplete turgor pressure regulation in the "terrestial" red alga, Bostrychia scorpioides (Huds.) Mont. Plant Sci. 61:29-36.

Karsten, U., Koch, S., West, J. A. \& Kirst, G. O. 1996b. Physiological responses of the eulittoral macroalga Stictosiphonia hookeri (Rhodomelaceae, Rhodophyta) from Argentina and Chile: salinity, light and temperature acclimation. Eur. J. Phycol. 31:361-368. 
Karsten, U., Michalik, D., Michalik, M. \& West, J. A. 2005. A new unusual low molecular weight carbohydrate in the red algal genus Hypoglossum (Delesseriaceae, Ceramiales) and its possible function as an osmolyte. Planta 222:319-326.

Kirst, G. O. 1990. Salinity tolerance of eukaryotic marine algae. Annu. Rev. Plant Physiol. Plant Mol. Biol. 41:21-53.

Kirst, G. O. \& Bisson, M. A. 1979. Regulation of turgor pressure in marine algae: ions and low-molecular-weight organic compounds. Aust. J. Plant Physiol. 6:539-556.

Lamare, M. D., Lesser, M. P., Barker, M. F., Barry, T. M. \& Schimanski, K. B. 2004. Variation in sunscreen compounds (mycosporine-like amino acids) for marine species along a gradient of ultraviolet radiation transmission within doubtful sound, New Zealand. N. Z. J. Mar. Freshw. Res. 38:775-793.

Lüning, K. 1990. Seaweeds: Their environment, biogeography, and ecophysiology. John Wiley \& Sons, New York, 527 pp.

Lv, Y., Sun, P., Zhang, Y., Xuan, W., Xu, N. \& Sun, X. 2019. Response of trehalose, its degrading enzyme, sucrose, and floridoside/isofloridoside under abiotic stresses in Gracilariopsis lemaneiformis (Rhodophyta). J. Appl. Phycol. 31:3861-3869.

Marcelino, V. R. \& Verbruggen, H. 2015. Ecological niche models of invasive seaweeds. J. Phycol. 51:606-620.

Maxwell, K. \& Johnson, G. N. 2000. Chlorophyll fluorescence: a practical guide. J. Exp. Bot. 51:659-668.

Muangmai, N., Preuss, M. \& Zuccarello, G. C. 2015. Comparative physiological studies on the growth of cryptic species of Bostrychia intricata (Rhodomelaceae, Rhodophyta) in various salinity and temperature conditions. Phycol. Res. 63:300-306.

Nelson, W. A. 1994. Distribution of macroalgae in New Zealand: an archipelago in space and time. Bot. Mar. 37:221-233.

Nelson, W. A. 2013. New Zealand seaweeds: an illustrated guide. Te Papa Press, Wellington, 328 pp.

Nelson, W. A., Dalen, J. \& Neill, K. F. 2013. Insights from natural history collections: analysing the New Zealand macroalgal flora using herbarium data. PhytoKeys 30:1-21.

Ramirez, M. E., Nuñez, J. D., Ocampo, E. H., Matula, C. V., Suzuki, M., Hashimoto, T. \& Cledón, M. 2012. Schizymenia dubyi (Rhodophyta, Schizymeniaceae), a new introduced species in Argentina. N. Z. J. Bot 50:51-58.

Ritchie, R. J. 1988. The ionic relations of Ulva lactuca. J. Plant
Physiol. 133:183-192.

Russell, G. 1987. Salinity and seaweed vegetation. In Crawford, R. M. M. (Ed.) Plant Life in Aquatic and Amphibious Habitats. Blackwell, Oxford, pp. 35-52.

Saunders, G. W., Birch, T. C. \& Dixon, K. R. 2015. A DNA barcode survey of Schizymenia (Nemastomatales, Rhodophyta) in Australia and British Columbia reveals overlooked diversity including S. tenuis sp. nov. and Predaea borealis sp. nov. Botany 93:859-871.

Scherner, F., Ventura, R., Barufi, J. B. \& Horta, P. A. 2013. Salinity critical threshold values for photosynthesis of two cosmopolitan seaweed species: providing baselines for potential shifts on seaweed assemblages. Mar. Environ. Res. 91:14-25.

Schweikert, K., Sutherland, J. E. S., Hurd, C. L. \& Burritt, D. J. 2011. UV-B radiation induces changes in polyamine metabolism in the red seaweed Porphyra cinnamomea. Plant Growth Regul. 65:389-399.

Shetty, P., Gitau, M. M. \& Maróti, G. 2019. Salinity stress responses and adaptation mechanisms in eukaryotic green microalgae. Cells 8:1657.

Simon-Colin, C., Bessières, M. -A. \& Deslandes, E. 2002. An alternative HPLC method for the quantification of floridoside in salt-stressed cultures of the red alga Grateloupia doryphora. J. Appl. Phycol. 14:123-127.

Sudhir, P. \& Murthy, S. D. S. 2004. Effects of salt stress on basic processes of photosynthesis. Photosynthetica 42:481-486.

Underwood, A. J. 1997. Experiments in ecology: their logical design and interpretation using analysis of variance. Cambridge University Press, Cambridge, pp. 140-197.

van Ginneken, V. 2018. Some mechanism seaweeds employ to cope with salinity stress in the harsh euhaline oceanic environment. Am. J. Plant Sci. 9:1191-1211.

West, J. A. \& McBride, D. L. 1999. Long-term and diurnal carpospore discharge patterns in the Ceramiaceae, Rhodomelaceae and Delesseriaceae (Rhodophyta). Hydrobiologia 398/399:101-113.

Wiencke, C. \& Läuchili, A. 1981. Inorganic ions and floridoside as osmotic solutes in Porphyra umbilicalis. Z. Pflanzenphysiol. 103:247-258.

Yancey, P. H. 2005. Organic osmolytes as compatible, metabolic and counteracting cytoprotectants in high osmolarity and other stresses. J. Exp. Biol. 208:2819-2830. 